\title{
Growth of Pleurotus ostreatus on short and long composted sawdust in a controlled environment.
}

\author{
Taiwo Esther Dada ${ }^{1}$, Fasidi, I.O. ${ }^{1,2}$ \\ ${ }^{1}$ Department of Plant Science and Biotechnology, Adekunle Ajasin University, \\ Akungba Akoko, Ondo State, Nigeria. \\ ${ }^{2}$ Department of Botany and Microbiology, University of Ibadan, Ibadan, Nigeria
}

\begin{abstract}
Mushroom cultivation has been suggested as a way to help in raising standard of living of people in developing countries by providing new source of protein. The study aimed at assessing the effect of compost fermentation (long and short-composting) on fruit body of Pleurotus ostreatus using agricultural wastes such as sawdust. These agricultural and sawmill wastes pose disposal problem and cause environmental pollution because they are either burnt or left to rot openly, there dry creating health hazard. Significant increase was obtained for long composted (35 days) and short composted (9 days) substrate as well as the control as the number of days after inoculation increased (Table 1). Long composted substrate (35 days) produced larger fruit bodies with significantly increase in the number of healthy fruiting bodies compared to uncomposted (control). Short composted substrate (9 days) had the least number of healthy fruit bodies; however there was no significant difference when compared to the control. The quantities of mineral element in P. ostreatus showed a common trend of increase from long composted to the uncomposted with preponderance of potassium $(\mathrm{K})$ and sodium $(\mathrm{Na})$ in both composted and uncomposted substrate. This study demonstrated that increasing yield and mushroom sizes can be obtained from experimental production on sawdust, and that it could be possible to shorten the production cycle of mushroom in order to improve the efficiency of mushroom production.
\end{abstract}

Keywords: Mushroom, compost, fermentation, Pleurotus ostreatus

\section{INTRODUCTION}

Pleurotus ostreatus has traditionally played an important role in the diet of people for a long time and were prized mostly for the flavour and condiment value. They are esteemed as succulent speciality food of delicate, subtle and agreeable texture. Edible mushrooms have been placed into five (5) categories \{Oso, 1975), according to their taste, morphology, growth habit, texture and habitant. Mycelial growth of Pleurotus species takes about some weeks or months. This mushroom mycelium grown in submerged culture is capable of producing materials with good nutritive value (Block et al, 1958) and has potential use as food, food additive or food supplement. Pleurotus species grow well in submerged culture (Zadrazil, 1978). Pleurotus species (Oyster mushroom) grown substrates such as corncob, wood shaving, straws, sawdust and vegetable wastes (Chang and Hayes, 1978). Additionally, edible mushrooms are grown on a great variety of cheap materials like industrial wastes and agricultural wastes which enhance their importance as a food material. Cultivation of Pleurotus species on logs and tree stumps was first studied at the beginning of the twentieth century (Zadrazil, 1978) and species which have been studied include $P$. ostreatus and $P$. 
saju caju. In a previoys study, Block et al (1958) made use of composted media of sawdust compost, corn cob-hay compost and sawdust-hay compost for the cultivation of Agaricus campetris and $P$. ostreatus. In the study, $P$. ostreatus produced fruit bodies readily on sawdust media. And hence conclude that good yields of mushroom can be produced from sawdust in comparison with yields obtained on commercial production of Agaricus campetris.

Biological advantages of compost as a soil amendment are well documented. By modulating the soil with billions of micro-organisms, the compost; stimulates the formation of aggregates (mycelia thread bio film) which improve soil structure, in some cases, it increases disease resistance competition, stimulates the indigenous soil micro flora with the food it provides, enhances resources and reduces the volume of waste products by more than $40 \%$, reduces pollution, as well as provides a quality organic amendment that can be used in flower beds, gardens or lawns to update the soil. With composted sawdust, there is partial degradation and makes the wood fibre which occurs during composting sawdust more easily digested by mushrooms. Mushroom cultivation has been suggested as a way to help in raising standard of living of people in developing countries by providing new source of protein.

Pleurotus species as a class of higher Basidiomycetes are known for their ability to convert agricultural wastes into edible proteins. The aim of this study was to assess the effect of compost fermentation (long and short-composting) on fruit body of $P$. ostreatus using agricultural wastes such as wheat bran and sawdust. These agricultural and sawmill wastes pose disposal problem and cause environmental pollution because they are either burnt or left to rot openly, there dry creating health hazard. By cultivating $P$. ostreatus on these wastes, their nutrient will be biologically recycled. This study was also carried out to determine mineral elements, protein, photochemical contents and enzyme activities in different developmental stages of the mushroom (Pleurotus ostreatus).

\section{MATERIAL AND METHODS Collection of materials:}

The substrate used was a mixture of different sawdust from mahogany tree (Swieteniamahagoni), Araba (Ceiba pentandra) and Iroko tree (Milicia excelsa), collected from Oka Akoko, Ondo State. The additive used for the cultivation of $P$. ostreatus was wheat bran obtained from feed mill, Ondo Road Akure, Ondo State, Nigeria. The spawn used for the experiment was supplied by Prof. I.O. Fasidi H.O.D Plant Science and Biotechnology Adekunle Ajasin University, Akungba Akoko, Nigeria. Spent compost used in this study was obtained by Prof. I.O. Fasidi from Zertech Nigeria limited Ibadan, the top soil (loamy soil) used was collected within the campus premises. Feed bag /jute bag to cover the heap of the compost, aluminum foil, rubber band and bottles are other material used for the cultivation and growth of Pleurotus ostreatus.

\section{Study location}

The study was conducted in the laboratory of the department, Mushroom house and nursery section of Adekunle Ajasin University, Akungba Akoko Ondo State. Nigeria.

\section{Sawdust composting for mushroom cultivation}

Sawdust (substrate) and wheat bran (additive) were thoroughly mixed in the ratio of 3:1 for short and long composting. Water was added until moisture level of about $70 \%$ was reached using the thumb test. The mixture was stacked to make a heap of $\operatorname{Im} x \operatorname{Im} x \operatorname{Im}$ (Length, breadth and height). 
For short compositing, the heap was stacked and turned as follows:

Day 0 -- $\quad$ stacking of heap.

Day $3-1^{\text {st }}$ turning and restacking.

Day $6-2^{\text {nd }}$ turning and restacking.

Day $9-\quad 3^{\text {rd }}$ turning and restacking (end of short compositing)

Temperatures and $\mathrm{pH}$ measurements were taken three times in a day morning, afternoon, evening) at the middle, and bottom of the compost heap. Turning, a process of disassembling and reassembling of compost was also done during intervals to allows compost aeration, full mixing of the composting and thereby prevent uneven decomposition.

For the long composting of sawdust, the heap was turned and stacked as follows:

Day $16 \quad--\quad 4^{\text {th }}$ turning and restacking

Day $23--\quad 5^{\text {th }}$ turning and restacking

Day $30 \quad--\quad 6^{\text {th }}$ turning and restacking

(End of long composting)

Temperatures and $\mathrm{pH}$ measurements were taken three times in a day morning, afternoon, evening) at the middle, and bottom of the compost heap. At the end of short and long composting, composted sawdust was sun dried to stop the enzymatic reaction and fermentation and stored dry.

\section{Effect of wheat bran (additive) on growth of $P$. ostreatus on composted sawdust}

The composted sawdust and wheat bran (additive) were weighed and thoroughly mixed in various ratios with a weighing balance. A comparison was then made between the level of additive $(10 \mathrm{~g}, 15 \mathrm{~g}$ and $20 \mathrm{~g}$ ) on the composted sawdust (40g and $35 \mathrm{~g}$, and $30 \mathrm{~g})$. Control $(50 \mathrm{~g})$ groups were added for each of the long, short compost sawdust and uncomposted sawdust treatments.

\section{Cultivation of Pleurotus ostreatus on sawdust}

Pre-weighed dry sawdust was mixed with small amount of water by using thumb test to ensure that the substrate is not logged with water. The mixed substrate was well packed into bottles covered tightly with aluminium foil and sterilized at $121^{\circ} \mathrm{C}$ for at least $45 \mathrm{mins}$ in the autoclave. After cooling, the substrate was inoculated with $20 \mathrm{~g}$ of the sorghum grain of $P$. ostreatus spawn and incubated at room temperature. After few weeks, mycelia had already ramified the bottles; the bottles were carried out and exposed to light, wet regularly until maximum fructification was obtained. The bottles were moved to secluded environment with relatively normal temperature to avoid tampering by pest, rodent, human etc.

\section{Determination of protein in the mushroom samples.}

This method measures the crude protein content present in foods because it gives the amount of all the reduced nitrogen in the food in the form of amines, ammonium compounds, urea, amino acids etc. The procedure involves digesting the materials with concentrated $\mathrm{H}_{2} \mathrm{SO}_{4}$ and converting the nitrogen to ammonium hydrogen sulphate. The digestion is accelerated by adding catalyst (potassium sulphate, mercury, selenium, or copper salt) to increase the boiling point. The mixture is made alkaline by adding $\mathrm{NaOH}$ solution. The $\mathrm{NH}_{3}$ produced is distilled into boric acid. The exact amount of $\mathrm{NH}_{3}$ is determined by titration with $\mathrm{HC} 1$. Proteins values are obtained by multiplying the total nitrogen by a factor of 6.25 . All analysis was carried out in duplicate. A blank was run first.

$\%$ Total Nitrogen $=\underline{14.01 \times(\text { sample titre-Blank titre }) \times \mathrm{N}}$

$$
10 \mathrm{x} \text { sample weight }
$$


$\mathrm{N}=$ Normality of the acid.

Therefore $\%$ protein $($ crude $)=\%$ Total nitrogen $\mathrm{x}$ conversion factor.

\section{Determination of Ash content}

Crucibles, one for each of the mushroom powdered samples, were washed and dried in the oven. They were allowed to cool in a desiccators and weighed. About two to three gram each of the dried sample materials were weighed into an empty porcelain crucible, which had been previously ignited and weighed. Each of the samples was ignited on a hot plate in the fume cupboard to char the organic matter. The crucibles containing the four samples were placed in a muffle furnace and maintained at a temperature of $600 \mathrm{C}$ for 6 hours. After which the sample were transferred directly to a desiccators to cool and their weights were immediately taken.

$\%$ Ash $=\underline{(\text { Weight of crucible }+ \text { ash })-(\text { Weight of empty crucible }) \times 100}$

\section{Sample weight}

\section{Determination of Mineral Element}

The ash of each sample obtained was digested by adding $10 \mathrm{ml}$ of $1.0 \mathrm{M} \mathrm{NH} \mathrm{NH}_{4} \mathrm{CI}$ to the ash in the crucible and heated to dryness on a heating mantle. About $10 \mathrm{ml}$ of $1.0 \mathrm{M} \mathrm{NH} \mathrm{NCI}_{4}$ was added again, heated to boil and filtered through a Whatman. No.1 filter paper into a $100 \mathrm{ml}$ volumetric flask. The filtrate was made up to mark with distilled water stopped and made ready for reading. The reading obtained was converted to percentage.

\section{Method of determining biological efficiency}

Fresh weights of harvested $P$. ostreatus fruit bodies were taken and the dry weight of substrate recorded. The values were then supplied for each set of substrate and additive used and the results.

Biological efficiency (B.E) $=$ Fresh weight of mushroom $\quad X \quad 100 \%$ Dry weight of substrate

\section{Data analysis}

All the data obtained from this investigation were analyzed by analysis of variance (ANOVA) in SPSS which was carried out to compare the difference at 5\% probability level differences between the treatments and control.

\section{RESULT AND DISCUSSION}

There was a general reduction in temperature but not below $45^{\circ} \mathrm{C}$ for the top (T1), middle (T2) and bottom reading (T3) of the long-composted sawdust (Figure 1a). Similarly there was an observed reduction in the $\mathrm{pH}$ values with increasing number of composting days (Figure 1b). Significant increase was obtained for long composted (35 days) and short composted (9 days) substrate as well as the control as the number of days after inoculation increased (Table 1). Long composted substrate of thirty five days produced the highest mycelial extension compared to the control. Primordial formation commenced after weeks after inoculation of the spawn substrate. The ensuing fruiting bodies took at least seven (7) days to mature. Long composted substrate (35 days) produced larger fruit bodies with significantly increase in the number of healthy fruiting bodies compared to uncomposted (control).

Short composted substrate ( 9 days) had the least number of healthy fruit bodies, however there was no significant difference when compared to the control. Result obtained for fresh weight $(\mathrm{g})$ of fruit bodies produced showed that the long composted substrate had the highest 
value compared to the control. The long composted substrate produced the highest percentage yield when compared to the control. However, there was no significant difference noticed between the short and uncomposted substrate (control) produced (Table 2). Considering the average percentage of protein and mineral composition of $P$. ostreatus using different levels of additives, while composition of phosphorus and potassium in the harvested Pleurotus ostreatus increased with increasing concentration of additives, concentrations of sodium generally reduced with increasing additive concentration (Table 3)

The highest mycelial extension was observed for long composted substrate. This was followed by short composted while the uncomposted substrate (control) had the least. Treatment of the substrate using different levels of additives enhanced mycelial extension. Other workers enhanced mycelial growth of mushroom by using additives. Quimio (1981) reported this observation for Auricularia species cultured on sawdust with 5\% super supplement producing the best growth. The growth of Lentinus subnudus in different substrate was attributed to its ability to secrete oxidizing and hydrolyzing enzymes (Fasidi and Kadiri, 1990). Primordial formation commenced after some weeks after the inoculation of spawned substrate. The ensuing fruiting bodies took seven (7) days to mature. More than two flushes were obtained for each substrate.

Table 1 show that long composted sawdust (35 days) had the highest mean number of healthy friutbodies which was significantly higher than those of the short composted substrate and uncomposted (control) substrate. The long composted substrate had the highest number of fresh weight of friutbodies. Similar results were observed in respect to the yield whereby the long composted substrate produced significantly higher yield than short composted and uncomposted (control) substrate.

Kadiri (1990a) obtained biological efficiency of $40 \%$ in two flushes for Lentinus subnudus cultivated on uncomposted rice straw substrate. The reason for this result could be because of long composting of substrate raw material using different additive with vary concentration. The significance of the present findings is that $P$. ostreatus, long composted substrate is better than short composted as well as uncomposted substrate (control). The quantities of mineral element in P. ostreatus showed a common trend of increase from long composted to the uncomposted with preponderance of potassium $(\mathrm{K})$ and sodium $(\mathrm{Na})$ in both composted and uncomposted substrate. Similar distribution of mineral elements was observed in Volvariella volvacea and P. tuber-regium (Kuforiji, 2005). Similar result was obtained by earlier workers (Khanna and Garcha 1982; Fasidi and Kadiri, 1990; Kadiri and Fasidi 1990a). The preponderance of potassium may be due to the more absorption and accumulation of this element from the substrate.

\section{CONCLUSION}

In the present work, it was shown that Pleurotus ostreatus can be cultivated on sawdust using different concentration of additives. In addition, this study demonstrated that increasing yield and mushroom sizes can be obtained from experimental production on sawdust, and that it could be possible to shorten the production cycle of mushroom in order to improve the efficiency of mushroom production. Sawdust and other agricultural wastes materials which are conceived as a negative factor in both the industrial and agricultural settings, since they generate diverse environmental effects related to the disposal. By cultivating $P$. ostreatus on these wastes, their nutrient will be recycled biologically. The significant of these present findings is that $P$. ostreatus. Long composted substrate is better than short composted and uncomposted substrate (control). In conclusion, cultivation of $P$. ostreatus on composted sawdust with wheat bran is recommended for use in farming settings. 


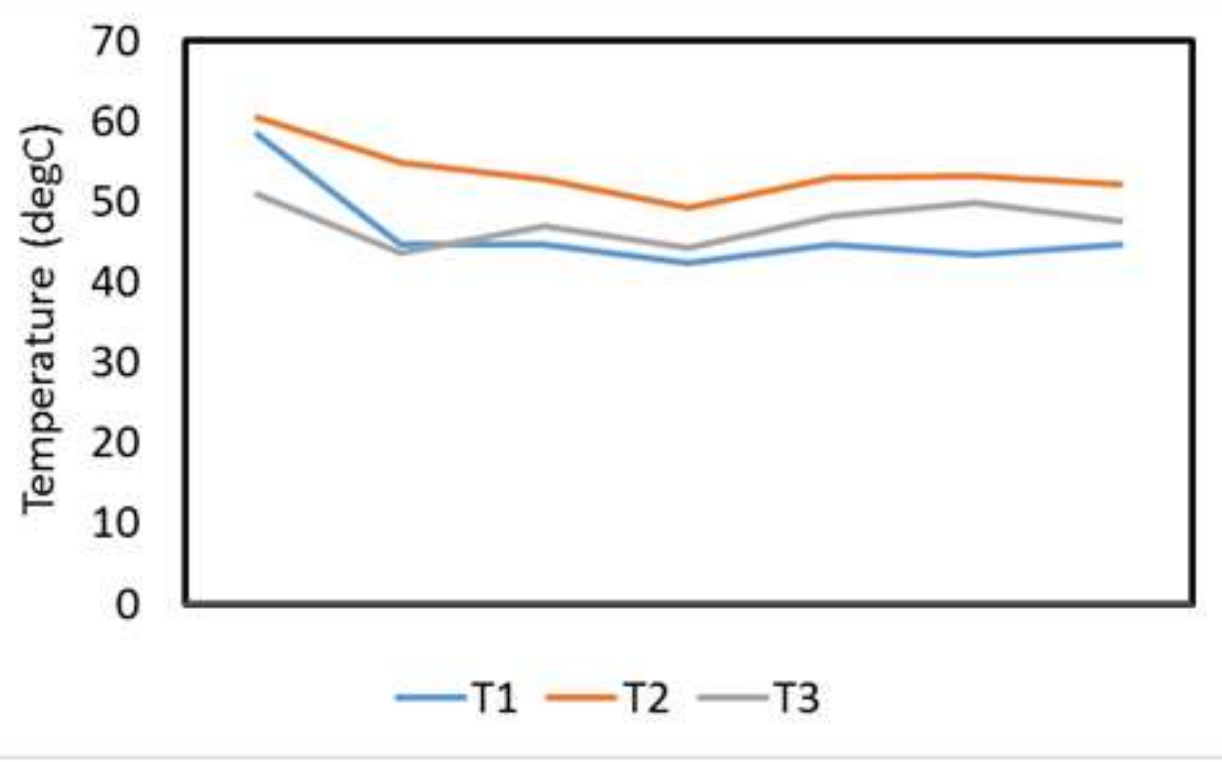

Figure 1: Tip -T1, middle -T2 and bottom - T3 temperature reading of long composted sawdust

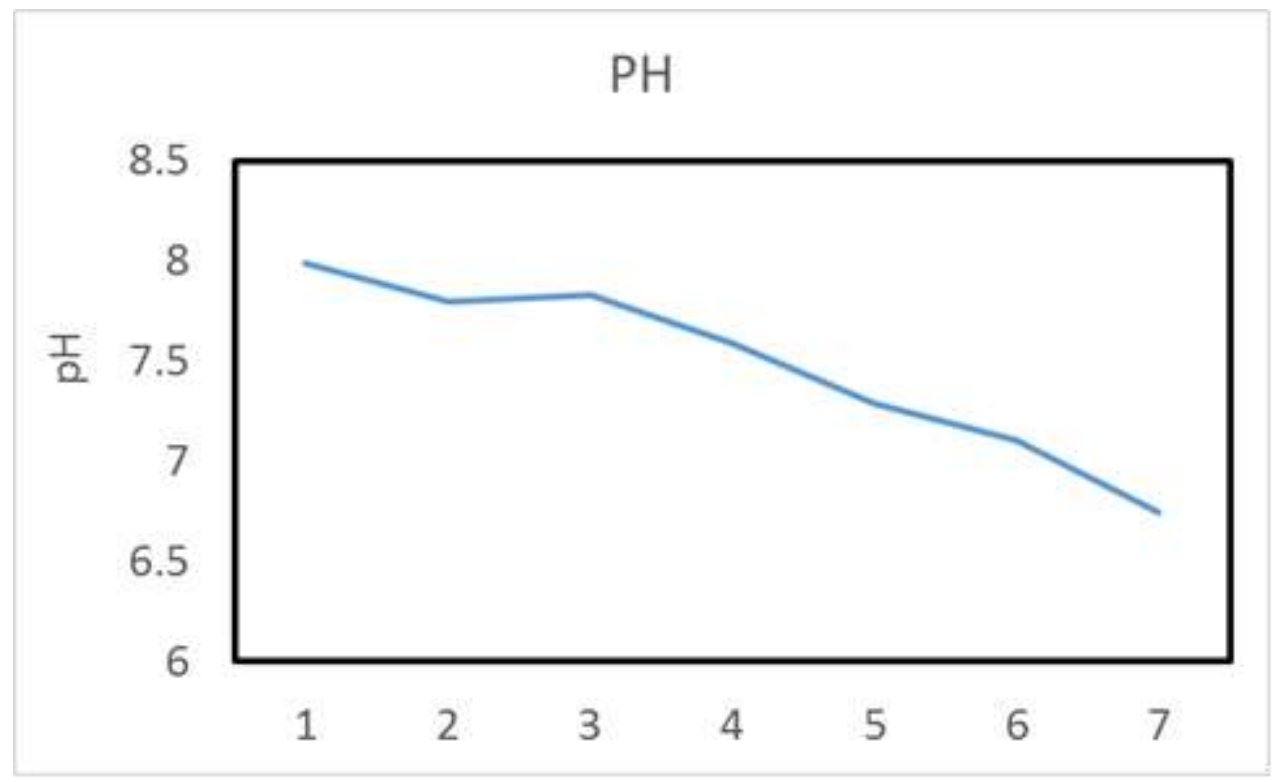

Figure 2: pH reading of long composted sawdust

Table 1: Fresh weight of mushroom harvested $(\mathrm{g})$ in the presence of additive

\begin{tabular}{ccccc}
\hline Mean weight(g) & $\mathbf{3 0 g}+\mathbf{2 0 g}$ & $\mathbf{3 5 g}+\mathbf{1 5 g}$ & $\mathbf{4 0 g + 1 0 g}$ & $\begin{array}{c}\mathbf{5 0 g} \\
(\mathbf{c o n t r o l})\end{array}$ \\
\hline Long composted substrate & $5.73^{\mathrm{a}}$ & $4.08^{\mathrm{a}}$ & $10.97^{\mathrm{a}}$ & $8.27^{\mathrm{a}}$ \\
Short composted substrate & $6.47^{\mathrm{b}}$ & $2.91^{\mathrm{ab}}$ & $2.53^{\mathrm{b}}$ & $3.84^{\mathrm{ab}}$ \\
Uncomposted substrate & & & & \\
\hline
\end{tabular}


Table 2: Percentage (\%) yield of $P$. ostreatus produced on long, short and uncomposted substrate

\begin{tabular}{lccc}
\hline \multicolumn{1}{c}{ Substrate types } & $\begin{array}{c}\text { Mean of } \\
\text { spawned } \\
\text { substrate }(\mathrm{g})\end{array}$ & $\begin{array}{c}\text { Mean of fresh weight } \\
(\mathrm{g}) \text { fruitbodies } \\
\text { produced }\end{array}$ & $\begin{array}{c}\text { Biological } \\
\text { efficiency }(\%) \\
\text { yield }\end{array}$ \\
\hline Long composted substrate & 20 & 6.26 & 12.52 \\
Short composted substrate & 20 & 3.94 & 7.88 \\
$\begin{array}{l}\text { Uncomposted substrate } \\
\text { control })\end{array}$ & 20 & 3.22 & 6.44 \\
\hline
\end{tabular}

Table 3: Average protein and mineral composition of $P$. ostreatus (long, short and uncomposted) (ppm) on different levels of additives

\begin{tabular}{ccccc}
\hline $\begin{array}{c}\text { Mean weight of } \\
\text { substrate/additive }\end{array}$ & $\begin{array}{c}\text { Phosphorus } \\
(\mathbf{p p m})\end{array}$ & $\begin{array}{c}\text { Potassium } \\
(\mathbf{p p m})\end{array}$ & $\begin{array}{c}\text { Sodium } \\
(\mathbf{p p m})\end{array}$ & $\begin{array}{c}\text { Average \% } \\
\text { protein }\end{array}$ \\
\hline Long composted & & & & \\
30g+20g & 2.10 & 5.22 & 1.83 & 28.23 \\
35g+15g & 1.90 & 6.61 & 2.62 & 30.02 \\
40g+10g & 0.50 & 1.59 & 7.83 & 32.49 \\
control (50g) & 1.00 & 2.00 & 6.31 & 31.60 \\
control sawdust (50g) & 0.80 & 1.33 & 4.03 & 27.97 \\
\hline
\end{tabular}

\section{REFERENCES}

Block, S. S., Stearns T. W., Stephens R. L., and Mccandless R. F. J. (1953). Mushroom mycelium, experiments with submerged culture. Journal of Agricultural and Food Chemistry. 1:890-893.

Block (1958) Mushroom Cultivation, Production of Mushrooms from Sawdust. Journal of Agricultural and Food Chemistry. $6: 12$

Chang, S.I. And Hayes, W.A (1978). The Biology and Cultivation of Edible Mushrooms. Academic Press. New York. Pp. 819.

Fasidi, I.O., Kadiri, M. (1990a). Changes in nutrient contents of two Nigerian mushrooms, Termilomyces robuslus (Beeli) Heim and Untinus sllhnudus Berk during sporophore development. Die Nahrung 34: 416- 420.

Fasidi, I.O., Kadiri, M. (1990). Variations in chemical composition chlorophyllum molybodies (Mayerex. Fr.) Massres and Pleurotus tuberregium (Fries) during fruitbodies development. Nigerian Journal of Physiological Sciences 24: 86-90

Kadiri, M. (1990). Cultivation of Lentinus squarrosulus on uncomposted substrate in Nigeria. Global J. and Applied Sciences 5: 41-44

Khanna, P. and Garcha H.S., (1982). Utilization of Paddy Straw for the Cultivation of Pleurotus Species. Mushroom Newsl. Topics 2 (1): 5-9. 
Kuforiji, O.O. (2005). Utilization of agro-wastes for the cultivation of Pleurotus tuberreguim (fr) MacayaLizano, A.V. (1988). Cultivo de Pleurotus ostreatus species afines sobies medios naturals semi-esteriles. Rev. Biol. Trop. 36:255-260.

Oso, B.A. (1975) Mushroom in Yoruba People Of Nigeria. Mycologia 67: 311 -319.

Quimio, T. H. (1976), Cultivation Ganoderma The Pleurotus-Way Mushroom Newsletter for Tropics,6: 12-13.

Quimio, T. H. and Sardsud, U. (1981). Nutritional Requirement of Pleurotus ostrestus (Fr). Phillippine Agriculturist 64(1): 79-89

Quimio, T. H., S.T Chang and D.J. Roysee, (1990). Technical Guidelines for Mushroom for Growing In the Tropics (FAO Plant Production and Protections Paper). Food and Agriculture Organization of the United Nations, Rome, Italy, Pp: 106

Sher, H.; Al-Yemeni, M. and Khan, K. (2011). Cultivation of the oyster mushroom (Pleurotus ostreatus (jacq.) p. kumm.) in two different agro-ecological zones of Pakistan. African Journal of Biotechnology 10: 183-188.

Zadrazail, H. (1978) Cultivation of Pleurotus Species. In S.T. Chang and W.A Hayes (Eds). The Biology and Cultivation of Edible Mushrooms. Academic Press. New York. Pp 521-557 